\title{
Knowledge about the Final Disposal of Nuclear Fuel in Sweden: Surveys to Members of Parliament and Citizens
}

\author{
Jenny Palm 1,2 \\ 1 The International Institute of Industrial Environmental Economics (IIIEE), Lund University, P.O Box 196, \\ 22100 Lund, Sweden; jenny.palm@iiiee.lu.se; Tel.: +46-46-222-02-42 \\ 2 The Swedish National Council for Nuclear Waste, 10333 Stockholm, Sweden
}

Received: 5 December 2019; Accepted: 12 January 2020; Published: 13 January 2020

\begin{abstract}
In 2011, the Swedish Nuclear Fuel and Waste Management Company (SKB) applied for a permit to construct a disposal facility. The Swedish government is expected to make a decision in 2020. Three surveys have been conducted to investigate how informed the Swedish Members of Parliament (MP) and the citizens are in these issues. The first study with the MPs was done in 2013, the second in 2016 and the one with the citizens was conducted in the winter of 2018/2019. The results show that most MPs and half of the citizens were aware of the ongoing permission process. Rather surprisingly, there were more politicians and citizens who knew about the suggestions to use copper canisters, than knew the suggested location. In general, nuclear waste was seen as an important issue by all respondents. A majority of the MPs and the citizens believed that Sweden can dispose the waste in a safe manner. Among the citizens, the trust in politicians' decisions on where and how to build a final repository were low and more trust was put into scientists and experts. Half of the citizens wanted to see a phase out of nuclear power, over half of the MPs meant that the repository should be designed so that the withdrawal of nuclear waste can be done.
\end{abstract}

Keywords: nuclear waste; survey; final repository; Sweden; politician; citizens

\section{Introduction}

Nuclear power has since the 1970s played an important role in the Swedish electricity mix. Sweden's first commercial reactor Oskarshamn 1 was put into operation in 1972. In 2019, there were 10 reactors in operation in three different nuclear power plants: Forsmark, Ringhals and Oskarshamn.

The total electricity production in Sweden amounted to 160 TWh in 2017. In 2017, electricity production was composed of $40 \%$ hydropower, $39 \%$ nuclear power, $11 \%$ wind power, and combined heat and power production $10 \%$ from district heating and industry, see Figure 1 [1].

Nuclear energy produces radioactive waste. In 2019, Sweden stored 6500 tons of nuclear waste in deep storage pools. The estimation is that Sweden will have 12000 tons if all existing plants are run as planned and no new ones are built. It is the Swedish nuclear industry that is responsible for finding a place and a method that entails a safe repository. To do this, the nuclear industry has formed the company Swedish Nuclear Fuel and Waste Management Company (SKB). In 2011, SKB applied for a permit under the Environmental Code and the Nuclear Activities Act to construct a disposal facility in Östhammar municipality. The method proposed is the so called KBS-3. KBS-3 is based on three protective barriers: copper canisters, bentonite clay and the bedrock. The plans are subject to approval by the Swedish Government [2]. 


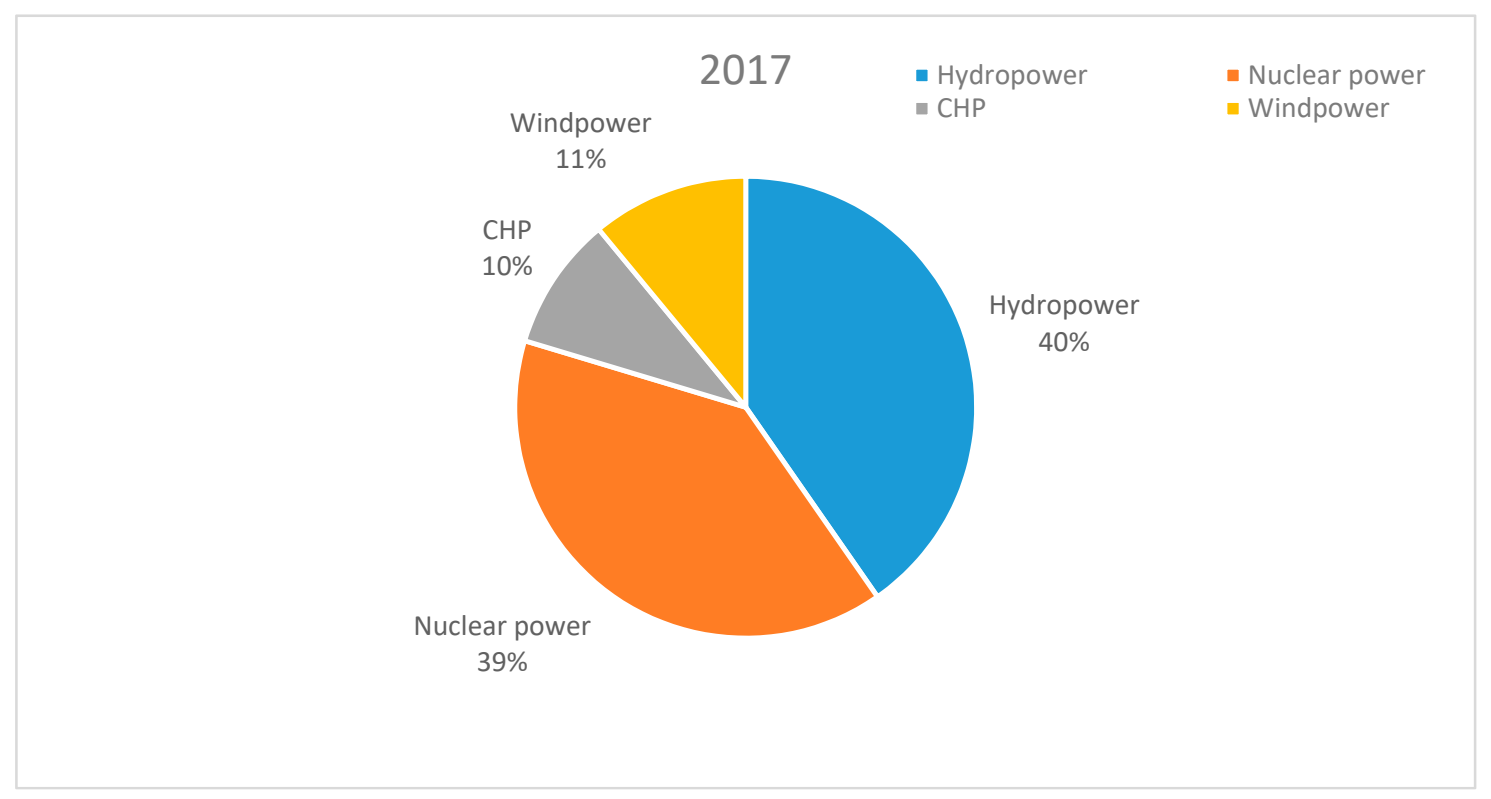

Figure 1. Total electricity production in Sweden 2017 [1].

The Swedish National Council for Nuclear Waste remit is to advise the Government on matters related to nuclear waste. The council has twice, in 2013 and 2016, investigated what information the Members of Parliament (MP) had about the nuclear waste issue and in which areas there are gaps in knowledge. In the winter of 2018/2019, a similar survey on knowledge about nuclear waste was done, but this time Swedish citizens were targeted. The aim of this article is to present, compare and discuss the results from these three surveys and also to identify areas that have not been discussed in public forums.

Previous studies have analyzed party political cleavages in parliament [3-7], local political controversies [8-11] and experts vs. politicians' influence in the process [12-14]. However, there are no previous studies on what information individual MPs have on issues relating to the disposal of nuclear waste. The citizens' view of the nuclear waste repository has been studied earlier. Over the years, both SKB and the Swedish Radiation Safety Authority (SSM) have conducted, but not published studies of the public's knowledge of and attitudes to nuclear waste. Sjöberg conducted a series of studies in 2001-2008 [15-20]. These were focused on risk perception, and e.g., to compare the perception of risk among young people and the elderly, as well as between residents of the Oskarshamn and Östhammar municipalities (that both have nuclear power plants) and other municipalities in the country. The results from those earlier studies show that men are more positive about a final repository than women, the elderly more than younger. When it comes to age, the younger respondents were not so interested in the issue.

\section{Materials and Methods}

Three surveys have been conducted since 2013. The first study was conducted in 2013 and targeted the politicians in the Swedish parliament (Riksdagen). Before the survey, an email was sent to all the MPs where the Swedish National Council for Nuclear Waste informed them that SKB had applied to the Land and Environment Court for permission to construct a final repository. In the same email, the MPs were informed about the coming survey on nuclear waste. The survey was conducted through telephone interviews done by a consultant company AB Samhällsinformation in November 2013. The same survey with the same procedure was then repeated in November 2016. The target group was MPs and the same questions were asked both times.

The gross sample was 349 MPs and both times reached 200, i.e., we had around $60 \%$ response rate each time. The significance level $95 \%$ has been used. 
Both times the party affiliation of the respondents in the survey reflected the composition in the parliament very well.

In 2018, a similar survey was conducted as shown in Table 1, but this time a statistical sample of the Swedish citizens were asked about their knowledge on the ongoing process to decide on a final repository. AB Samhällsinformation was again commissioned to conduct telephone interviews with a representative selection of 1000 citizens between 18 and 75 years. For the survey, a random selected sample was purchased from the company Bisnode $\mathrm{AB}$. The response rate was $67 \%$, i.e., 670 citizens responded. The loss mainly consists of people not answering their phone. The significance level $95 \%$ has been used. The younger age group and women were more difficult to reach than the older and the men. We adjusted the data to reflect the strata in the population.

Table 1. The three surveys with target groups and response rates.

\begin{tabular}{cccc}
\hline Year the Survey Was Conducted & Target Group & Total Population & Response Rate \\
\hline 2013 & Members of Parliament & 349 & $60 \%$ \\
2016 & Members of Parliament & 349 & $60 \%$ \\
$2018 / 19$ & Citizens between 18-75 years & 1000 & $67 \%$ \\
\hline
\end{tabular}

The results from the surveys will be presented below. When we have asked the same or similar questions to the MPs and the citizens, the results are shown in one diagram. Some questions were only asked to the MPs or to the citizens and those are presented separately.

\section{Results}

The first question in all surveys concerned if the respondent's knew that a final repository for nuclear waste was planned in Sweden. The questions to the MPs and the citizens were differently formulated, where the citizens had an easier more straightforward question compared to the one to the MPs: The question to the citizens was: Do you know that a final repository for nuclear waste is planned in Sweden? The question to the MPs reflected the fact that the Swedish National Council for Nuclear Waste had sent an email some weeks before the interview to inform the MPs about the ongoing application to the Environmental Court. The question to the MPs was formulated as: Are you aware that SKB applied to the Land and Environment Court and the Swedish Radiation Safety Authority for permission to plan for the disposal of high level nuclear waste? The results are shown in Figure 2.

It appears that there was relatively good knowledge of the current process among the MPs. There was no significant difference between the parties or between the sexes. The knowledge seems to be less in 2016 compared to 2013, which was an unexpected result. We assumed that the knowledge would have increased due to the ongoing application process, but this was not the case. The decline remains, however, within the margin of error. No deviations with regard to gender but on party affiliation. Significantly more Swedish Democrats did not know or were uncertain. The Swedish Democrats is a rather new nationalist and social conservative party that entered the Swedish parliament in 2010. The Swedish Democrats and the conservative Moderate Party had a tendency to respond in a similar way in the survey. In the same way, the Left party and the Green party had a tendency to respond in similar ways.

Fifty-five percent of the citizens knew that a final repository was planned in Sweden and $45 \%$ did not know about this. Significantly more men than women said they knew about this.

The final repository is planned to be located in Östhammar municipality. Östhammar is where the nuclear plant Forsmark is also located. The second question concerned if the respondent knew in which municipality a repository was planned to be located. It was an open question, where no alternatives were given. Some answered Forsmark, mixing the name of the municipality with the name of the nuclear plant and these responses are presented together. The results are shown in Figure 3. 


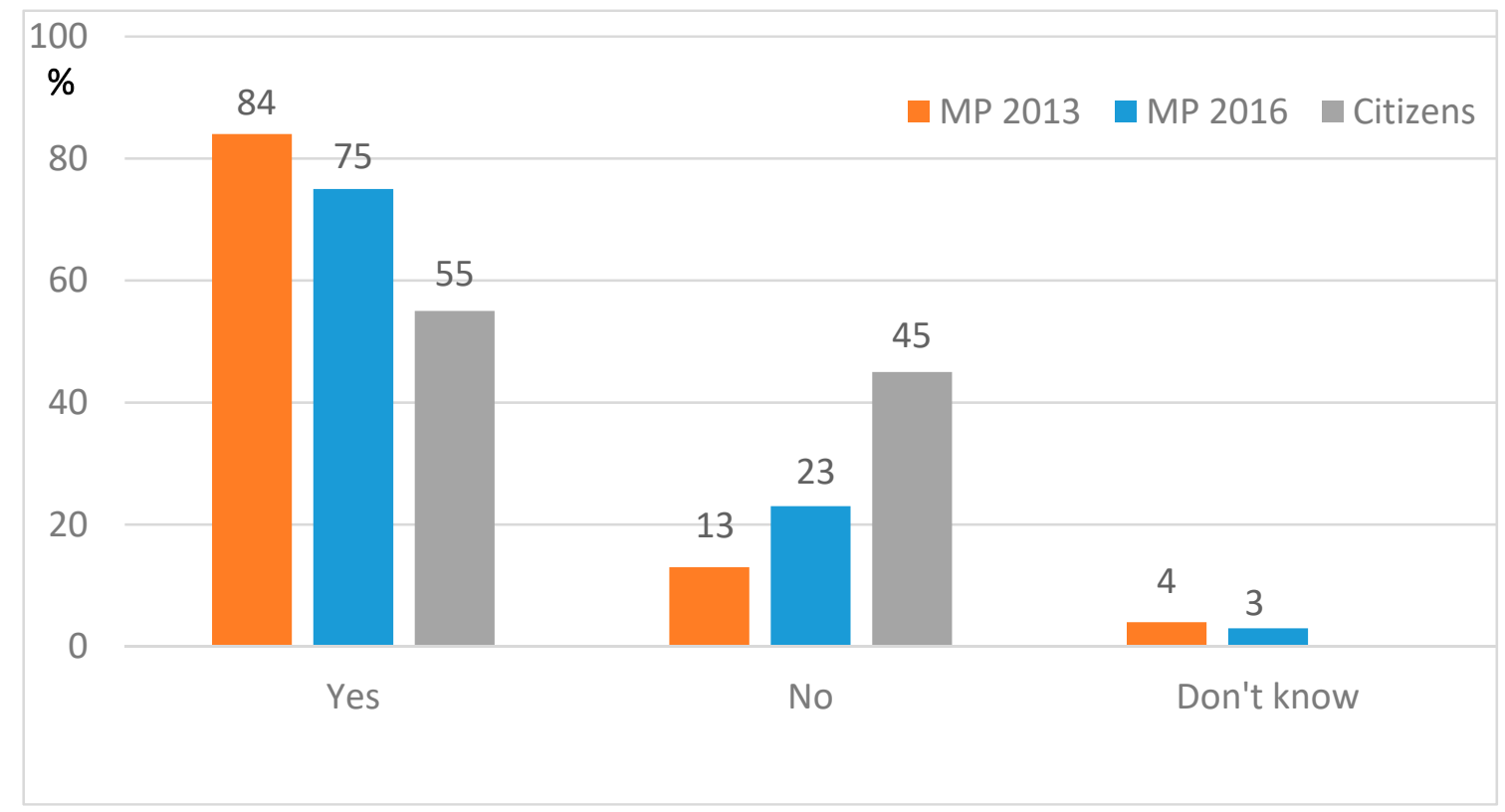

Figure 2. Question to the MPs: Are you aware that SKB applied to the Land and Environment Court and the Swedish Radiation Safety Authority for permission to plan for the disposal of high level nuclear waste? Question to the citizens: Do you know that a final repository for nuclear waste is planned in Sweden?

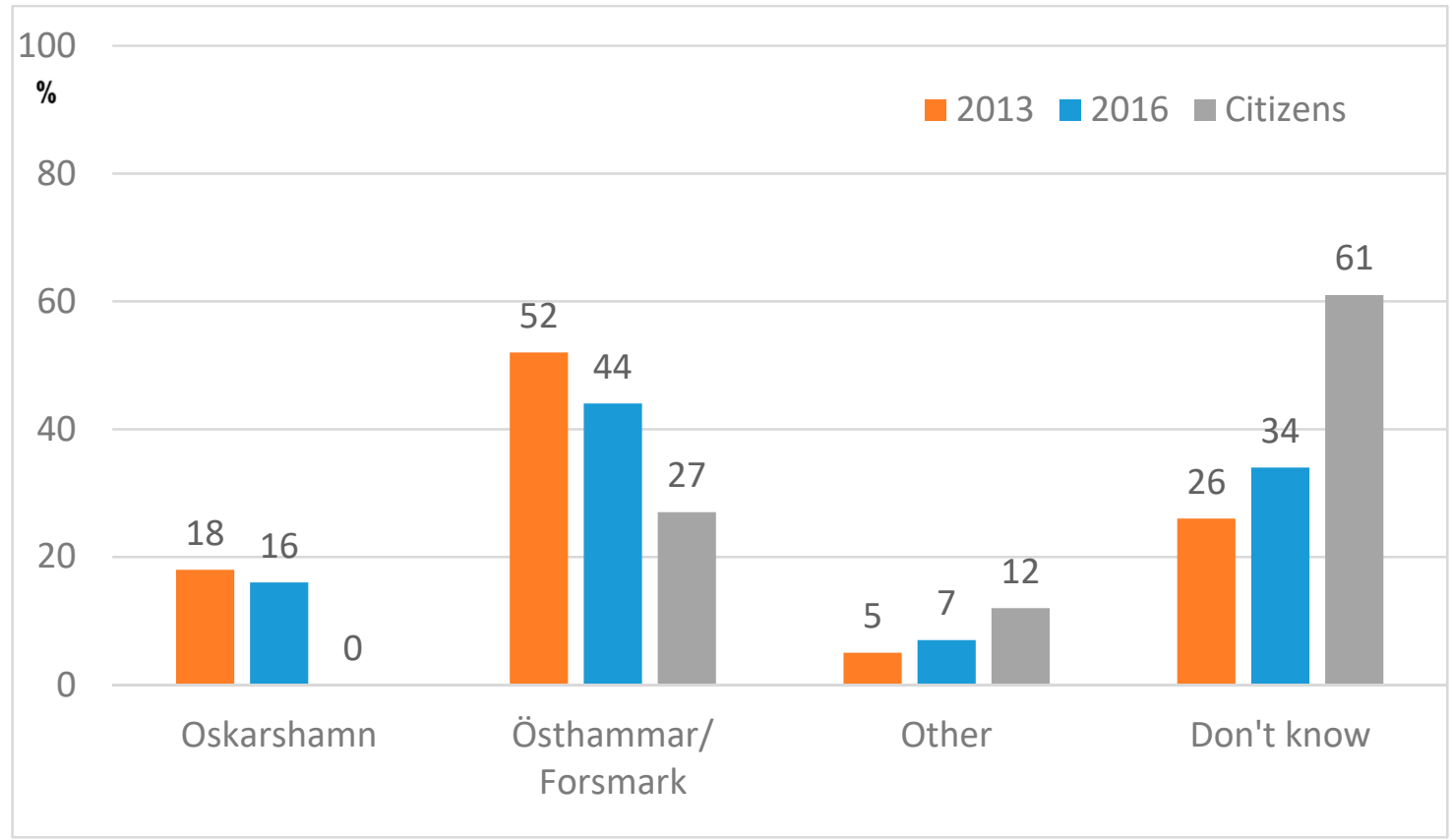

Figure 3. Question: Do you know where the repository will be located?

Again we got a surprising result, when it turned out that more MPs in 2013 compared to 2016 knew that Östhammar was the suggested location. The location is an issue that should be high on the political agenda and where we thought more politicians would be informed, especially when coming closer to a decision on the matter. In 2013, 52\% of the MPs responded Östhammar or Forsmark, in 2016 this figure was down to $44 \%$. In 2016, 34\% of the MPs responded that they did not know the location, in 2013 that figure was 26\%. Women responded in both surveys to the MPs to a higher degree "Don't know" compared to the men. 
Oskarshamn was the other municipality investigated for a final disposal and a central interim storage facility for spent nuclear fuel is located here, which is why so many MPs thought that Oskarshamn was the suggested location.

More than $60 \%$ of the citizens could not answer where the final repository is planned to be located. Of those that did know, 27\% answered that the repository is planned to Forsmark or Östhammar. Significantly more men responded Forsmark (29\%) compared to women (9\%).

One question concerned what solution SKB has suggested in their application. The suggested solution is to have a sealed copper canister in a disposal hole under a granite bedrock backfilled with bentonite. In the responses, multiple answers were possible, but most responses chose one, and most chose the copper canister, see Figure 4.

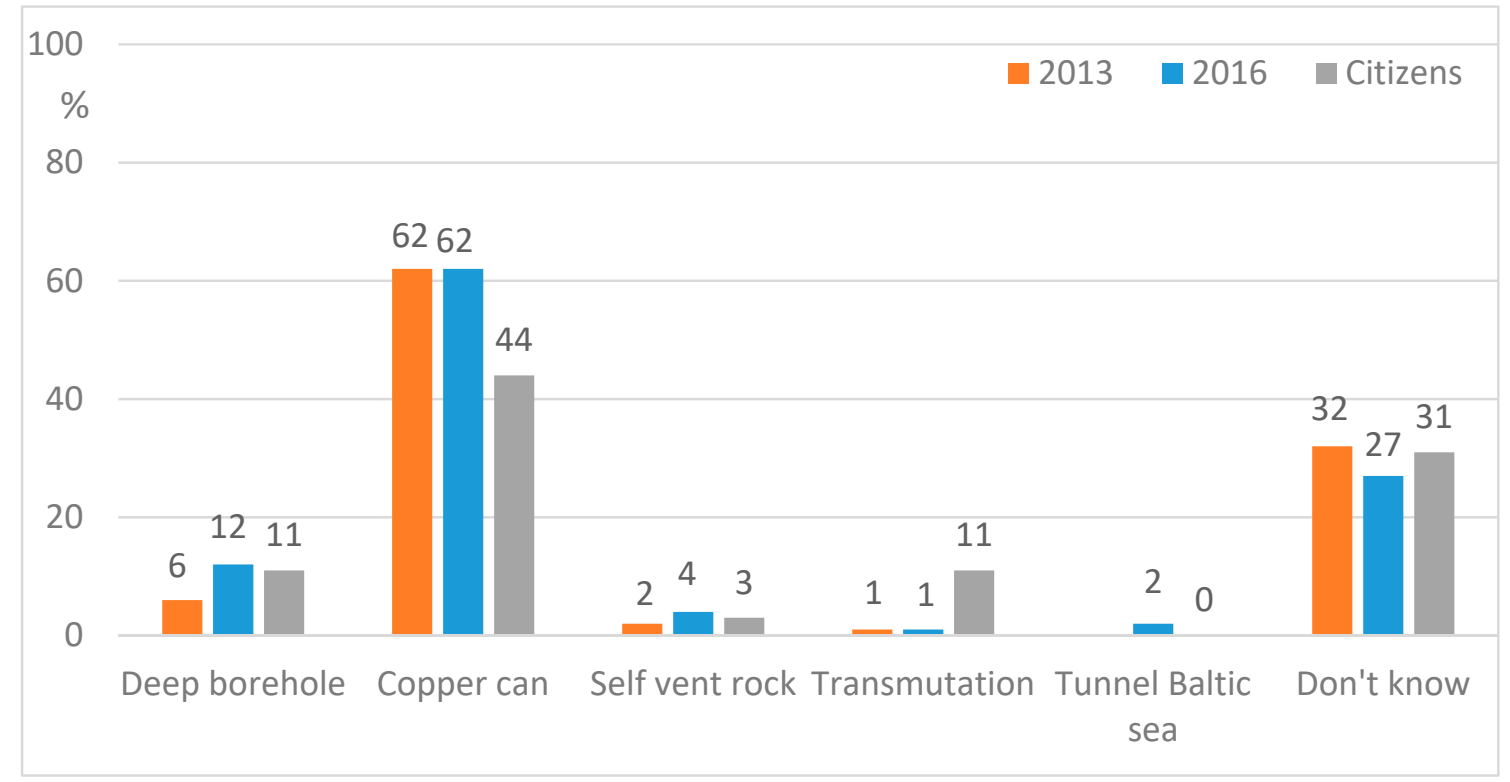

Figure 4. Which solution for final repository does SKB suggest in its application concerning spent nuclear fuel?

In the surveys to the MPs there were no differences between how the parties answered. Most MPs answered the copper canister or that they did not know. Copper canister received the most answers also from the citizens. Significantly more men responded copper canister (56\% compared to $32 \%$ for women). Persons aged 66-75 responded this to a significantly higher degree than other age groups (58\%).

The Swedish media since 2014 has reported about an ongoing scientific conflict concerning corrosion in the copper canister and this is probably the main reason why so many respondents knew about the use of a copper canister. In all three studies there were more respondents who knew about the technical design of the final repository than the actual location, which raises questions about the type of information that reached the public and if that information should be expanded.

One question concerned if the respondents thought that Sweden can handle and dispose the waste safely or not, see Figure 5.

In 2016, 69\% of the MPs believed that Sweden can safely handle the waste. Three years earlier, $64 \%$ thought so. In both measurements, the women were more doubtful about this.

Among the citizens, $58 \%$ responded Yes, $18 \%$ No and $25 \%$ were unsure. The women were more negative, $21 \%$ responded No, while $14 \%$ of the men said No. However, also among the women more than half responded Yes. 


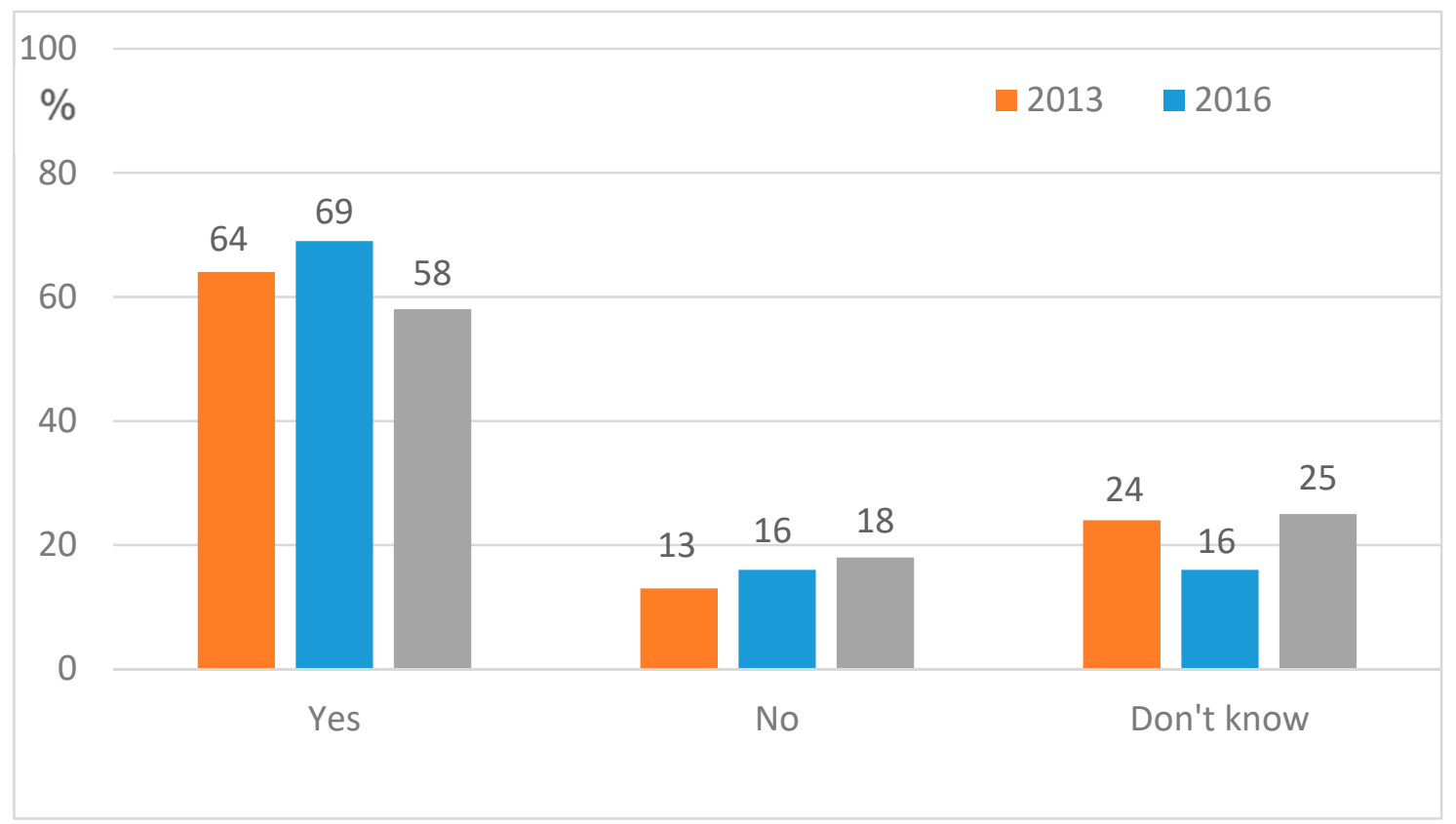

Figure 5. Do you think that we in Sweden can manage and dispose nuclear waste safely or not?

One question in the survey concerned how important an issue the respondents found nuclear waste to be. To the MP, the question was phrased as "How important political issue do you think the final disposal of spent nuclear fuel is?". The respondents could respond on a scale of 1 to 10 , where 1 meant "not at all important" and 10 meant "very important political issue". It was also possible to respond "Don't know". Almost all MPs considered the final disposal of spent nuclear fuel as an important political issue. The mean was 8.2 (in 2013) and 7.8 (in 2016) on the 10-degree scale. Women as well as members of the Green Party felt that this was a very important political issue. The Moderates and the Swedish Democrats were slightly below average. In both the 2013 and the 2016 survey, 2\% responded "Don't know".

The citizens were asked how important an issue they thought it was, excluding "political" from the question. The citizens responded to a scale of 1 to 5 where the number 1 meant "not at all important" and the number 5 meant "very important". Also the citizens could choose to respond "Don't know". The average value was 4.4 at the total level, i.e., also the citizens thought this was an important issue. No significant deviations in terms of gender were found. The only significant deviation was that the respondents +56 years old to a higher degree than others thought it was an important issue. For them, the mean value was $4.7 ; 1 \%$ of the citizens responded "Don' $t$ ' know".

As showed above, the majority of the MPs considered that nuclear waste was an important political issue. This question was followed by a question about if the MPs thought Sweden should leave the decision to experts on how to manage nuclear waste. The results are shown in Figure 6.

At a total level, $75 \%$ and $76 \%$ of the MPs responded that it should not be left to the experts to decide on the issue. No differences with respect to gender were identified. The Social Democrats was more negative to "expert opinions" than others. (The Social Democrats held government power continuously from 1936 to 1976 . After the 2018 election, the party is in a coalition government with the Green Party). Among the Swedish Democrats significantly more believed that the decision should be transferred to experts (37\% vs. 19\% at total level). In total only 19\% thought that the issue would be left to experts. This indicates a potential for thriving political discussions in the parliament, but this has not been the case so far [21]. 


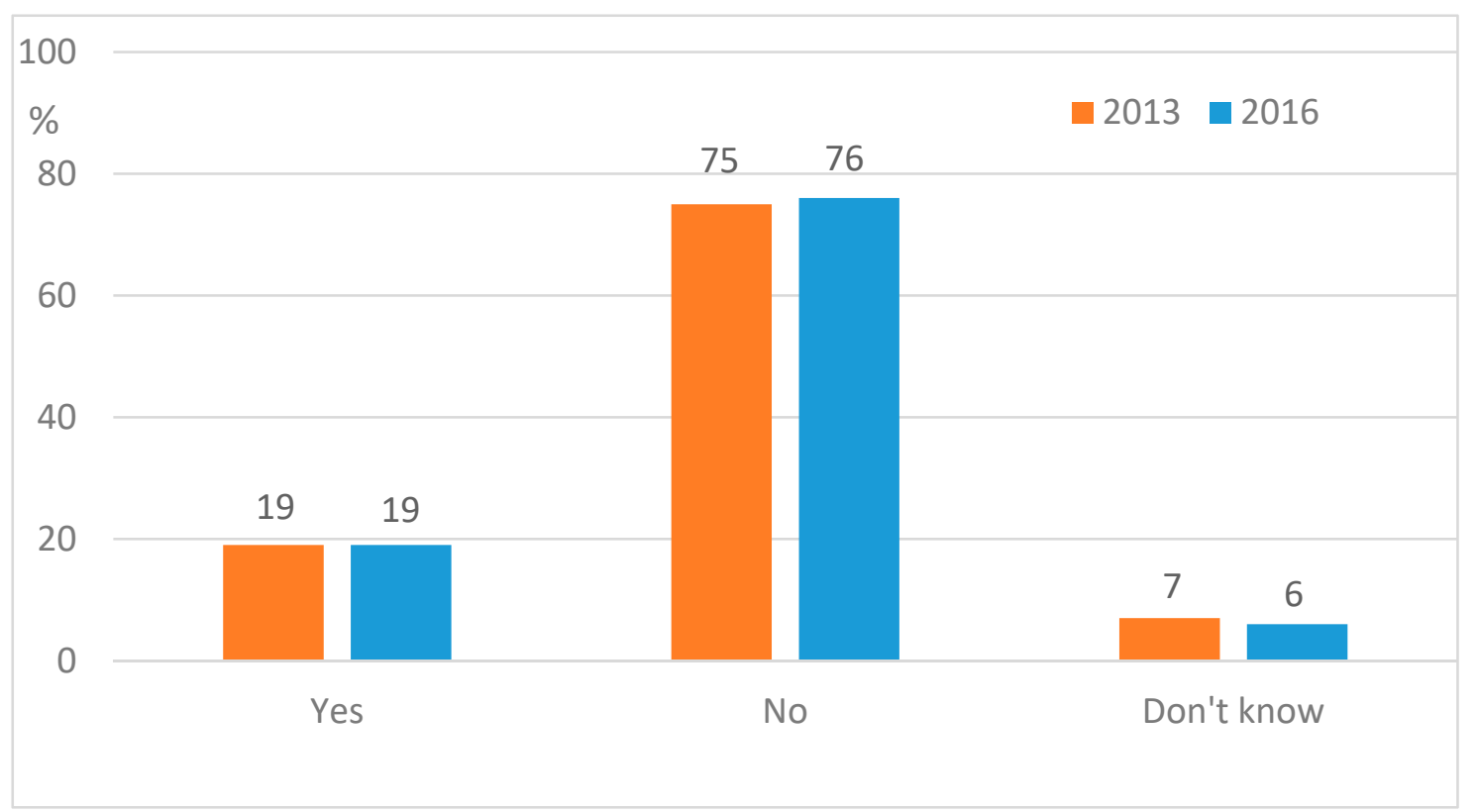

Figure 6. Question just to the MPs: Do you think we should leave it to the experts on nuclear waste to decide about how we should manage our nuclear waste?

The citizens received another version of this question. Three questions were asked, related to how much the citizens trusted (1) politicians, (2) authorities and (3) scientists and experts to deal with issues related to the final disposal of spent nuclear fuel. The three questions were posed as: "I trust the politicians'/authorities'/scientists and experts' decision/investigation on where and how the final repository of spent nuclear fuel should be built." The citizens could choose to respond "I totally agree", "I agree partly", "I disagree partly", "I totally disagree" or "Don't know". In Figure 7, the responses from all three questions are compiled.

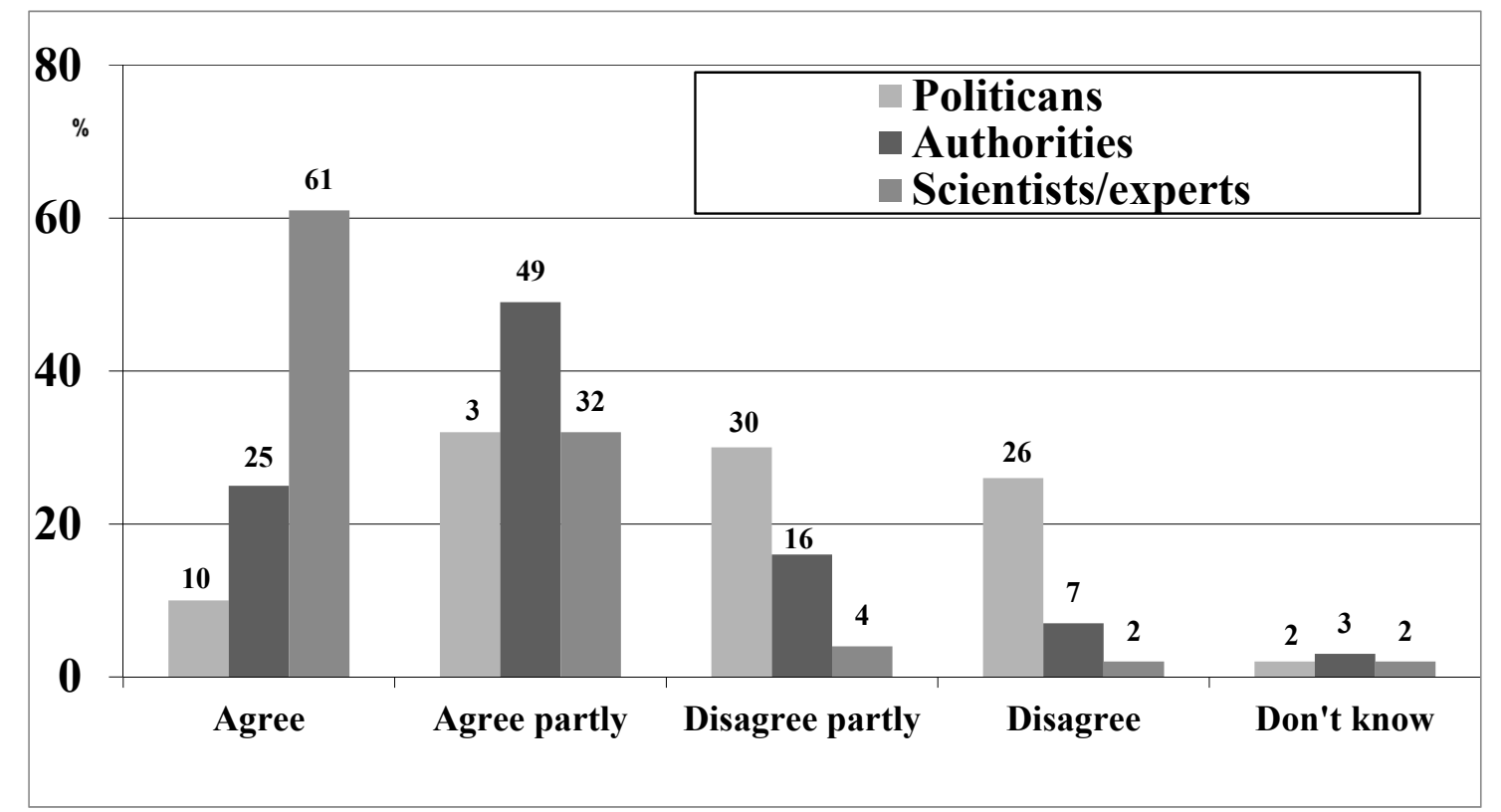

Figure 7. Question just to the citizens: I trust the decisions/investigations by the politicians'/ authorities'/scientists and experts' on where and how to build a final repository.

In Figure 7, it is shown that the trust in politicians was low. No significant differences among groups can be detected. The respondents had more trust in authorities than in politicians. Respondents 
with higher education trusted authorities more than those with lower education. Most trust did the respondents have to scientists and experts. How the respondents defined an expert or scientist is unclear, but most likely it is an expert in the nuclear field that the respondents had in mind. That more trust is put into scientists and experts can be a reflection of the technological focus in the public debate. It is the Swedish Government that will make the final decision on a final repository and the low trust in politicians might become a legitimacy problem in the future.

In one question only posed to the citizens, the interviewer read some different threats (the threats were read in a random order every time) and the respondents were asked to answer on a 10-degree scale how concerned they were for the issue; 10 meant that they felt very strong concern and 1 meant no worry at all. The mean value is shown in Table 2.

Table 2. The concern the citizens felt for different threats.

\begin{tabular}{|c|c|}
\hline Threats & $\begin{array}{c}\text { Mean Value of the Responses on a 10-Degree } \\
\text { Scale Where } 1 \text { Meant No Worry at All and } 10 \\
\text { Meant Strong Concern }\end{array}$ \\
\hline Climate change due to overuse of the Earth's resources. & 7,7 \\
\hline War and conflicts around the world & 6,8 \\
\hline $\begin{array}{c}\text { Violence and gang-related shootings both in Sweden and } \\
\text { in our surroundings }\end{array}$ & 6,7 \\
\hline $\begin{array}{c}\text { Uneven distribution of the Earth's resources leading to } \\
\text { poverty and starvation. }\end{array}$ & 7,4 \\
\hline $\begin{array}{c}\text { Overuse of antibiotics leading to the establishment of } \\
\text { resistant bacteria. }\end{array}$ & 7,5 \\
\hline $\begin{array}{c}\text { Air pollution due to coal burning and emissions from } \\
\text { industries and aviation. }\end{array}$ & 6,8 \\
\hline Radioactive spent nuclear fuel from nuclear power plants. & 5,7 \\
\hline
\end{tabular}

The most interesting result was that concern for radioactive spent nuclear fuel came as the last alternative. Throughout, more women than men expressed concern about the various alternatives above. Climate change worried more people in metropolitan areas compared to those living in sparsely populated areas.

We ended the survey to the citizens by asking how they would vote if Sweden would have a referendum about future nuclear power. They could choose between four pre-defined answers and "Don't know". The results are shown in Figure 8.

As shown in Figure 8, 46\% of the respondents chose option 1 or 2, i.e., they wanted to phase out nuclear power directly or as soon as possible. Twenty-six percent chose option 4 and wanted to invest in new nuclear power; $58 \%$ of the women chose alternatives 1 or 2 ; while the corresponding figure for men was $34 \%$. Younger people (18-25 years) chose option 2 to a greater extent, while the older people $(66$ years + ) chose option 3 and thought Sweden should continue to use the nuclear power already existing.

The final questions to the MPs were only posed to the MPs and concerned if the MPs believed that Sweden should construct a final disposal in a manner that allows for reuse in the future, see Figure 9. In this question, the respondents who said Yes, were asked to define if they meant "Yes, definitely" or "Yes, maybe". 


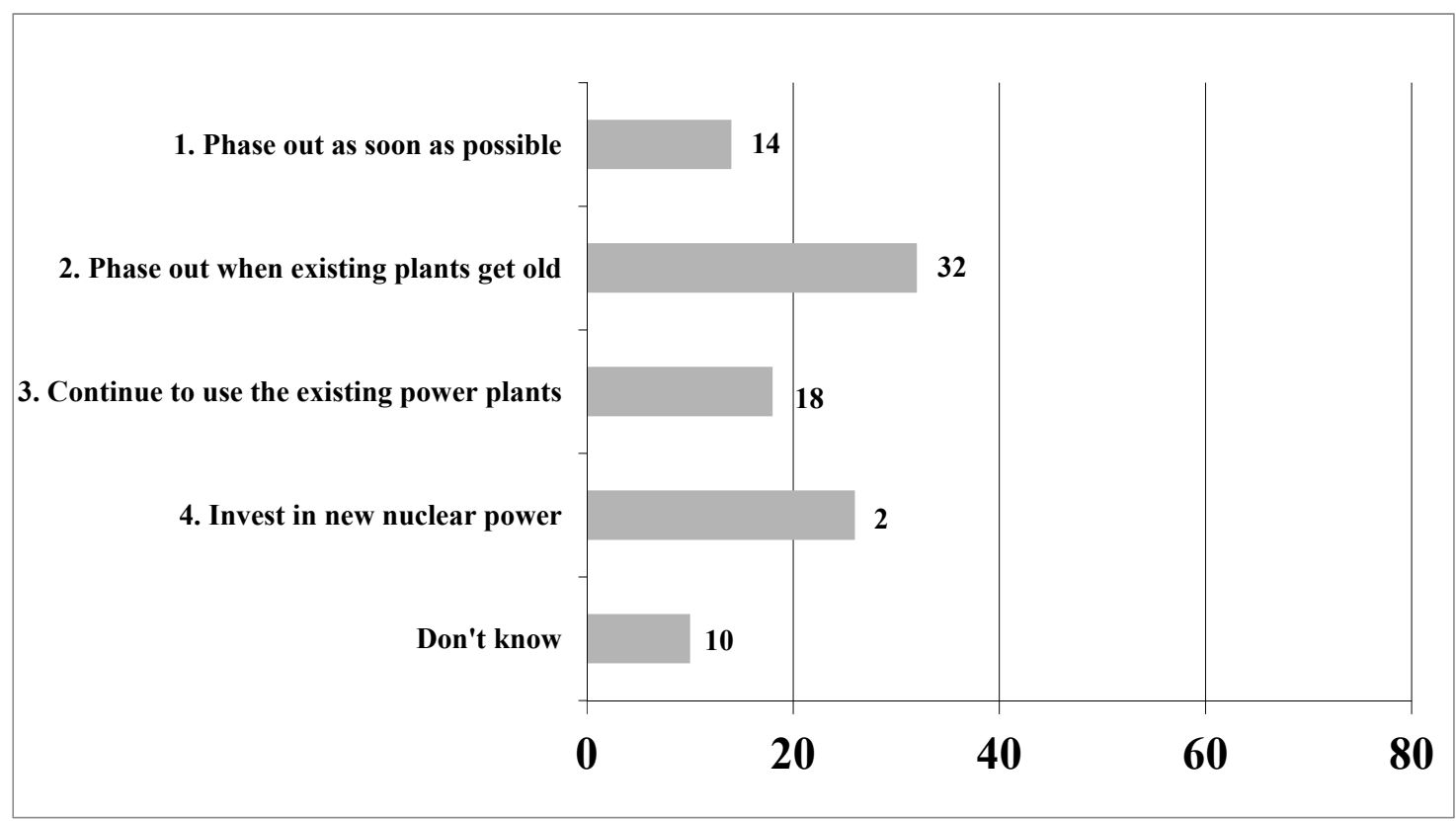

Figure 8. Question just to the citizens: If we today would have a referendum about future nuclear power, how would you vote?

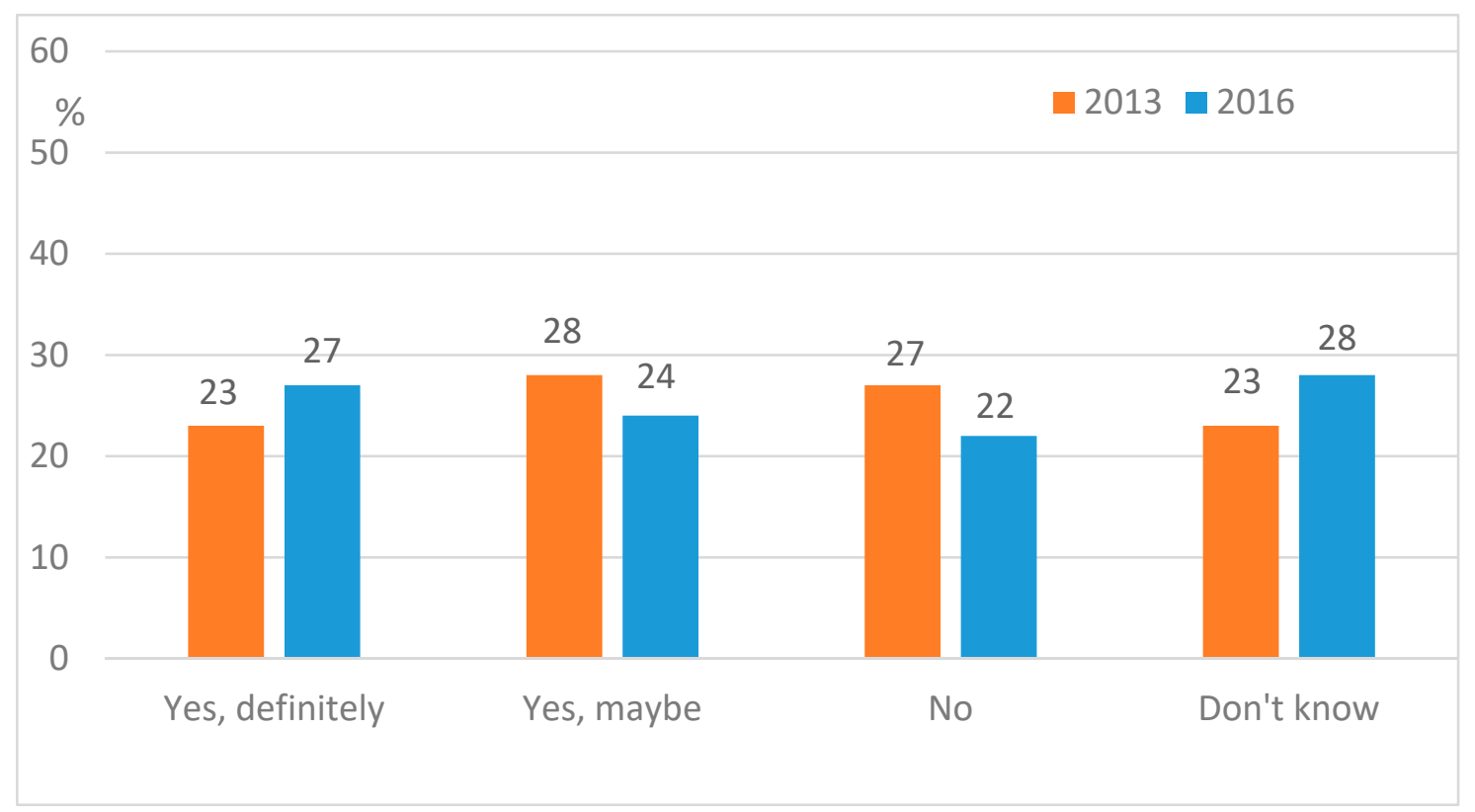

Figure 9. Question just to the MPs: Do you think nuclear waste should be disposed in a manner that allows it to be readmitted, for example to be reused in new types of nuclear reactors?

The issue of retrievability is a question that is not on the agenda in Sweden. It is not discussed by $\mathrm{SKB}$ or in the public debate. From this perspective, it was an unexpectedly large number, over half, which responded Yes, i.e., that Sweden should construct a final disposal in a manner that allows for reuse in the future. The Moderate Party, the Liberal Party and the Swedish Democrats were most positive, while the Green Party and the Left Party were the most skeptical. No gender differences were detected. This implies that even this issue should be given access to the public debate and be up for discussion. 


\section{Discussion}

The final repository of spent nuclear fuel is a technical system that needs expert knowledge [2]. A technocratic norm characterizes the nuclear waste issue, where there often is a tendency to believe that the problem is best solved through enough expertise and detailed knowledge in a matter [22]. In such a discourse, the discussion is characterized by "apolitical problem solving" and moral arguments are perceived as opinions and not useful information [23]. Part of the technocratic norm is that the public's knowledge is regarded as deficient and that citizens are involved in order for them to better understand a question and to accept scientific knowledge [24]. However, this view has become increasingly criticized in favor of an emphasis on involving politicians and citizens in the process, as these can contribute substantially. Dialogues with citizens and their political representatives on issues related to science and technology, such as the nuclear waste issue, is an important part of the solution to a complex problem.

It is therefore important to increase knowledge about what information the MPs and the citizens have and how they perceive the nuclear waste issue, which the presented surveys has contributed to. We saw that most of the MPs were aware of the ongoing application process. A partial explanation for this could be that in the introductory letter to the MPs before the telephone interviews, they were informed about the ongoing process. The citizens were less aware about this. Almost half of the citizens did not know that a final repository was planned in Sweden.

There were some differences between women and men. A general trend was that women seemed to be more unsure compared to the men and more often opted for the answer "Don't know". The men also had a tendency to know more about the issue than the women, which was a result valid in all three surveys. This indicates that the issue so far has attracted less interest from women than from men. One explanation for this can be the technical character the discussions have in media mainly focusing on the construction of the barriers and especially the copper canister. In the survey to the citizens, it was the women and the older that worried most for all the different threats listed and also for nuclear waste.

When it came to the suggested location of a final repository, half of the MPs knew Östhammar was suggested, while $27 \%$ of the citizens were aware of this. A rather unexpected result was that more respondents knew the capsule material than knew that the municipality Östhammar was suggested as a location for the final repository. This indicates that technical issues have had a lot of focus in the public debate and on the political agenda. These technical aspects are probably hard for both the politicians and a general public to have an opinion on. It seems more appropriate to discuss issues as location and risk perceptions in the public.

In general, nuclear waste was seen as an important issue. Only $20 \%$ of the MPs thought that the issue would be left to experts. This might be a reflection of what happened in the US where the experts suggested Yucca Mountain for final disposal of nuclear waste, but the public did not follow this advice [25]. This result also indicates a potential for thriving discussions in the future, but it also demands someone eager to initiate a discussion. So far this has not been the case in Sweden [21].

A majority of the MPs and the citizens believed that Sweden can dispose the waste in a safe manner. Among the citizens, the trust in politicians' decisions on where and how to build a final repository were low and more trust was put into scientists and experts. This can be a reflection of a technological rather than a political/ideological focus in the debate [26]. In this question, it seems like the public has more trust in the scientists and experts than the MPs had, but this is a conclusion not possible to validate from the material. The questions to the MPs and the citizens were not equally posed and the questions had different meanings. This is, however, a question worth investigating further in future research.

Nearly half of the citizens wanted to see a phase out of nuclear power, which is an expected outcome. This is in line with, for example, the results from the SOM-institute who regularly check Swedes' opinions on e.g., energy sources [27]. 
The issue of retrievability is, as mentioned above, not an issue on the Swedish agenda [26], but the way the repository is suggested to be built, retrievability will be possible. We therefore asked the MPs about their views on retrievability and it was an unexpectedly large number, over half, which meant that the repository should be designed so that the withdrawal of nuclear waste can be done. This means that even this issue should be given access to the public debate and be up for discussion.

In the future planning process, it is important not only to involve the MPs and the citizens, but also to approach them with relevant issues and issues where they will have possibilities to contribute with relevant perspectives. The design of copper canister is probably not the best issue to discuss by laymen, but issues concerning retrievability, where the waste should be stored, and how to inform today and future generations are all issues relevant for public debate.

Funding: This research received no external funding.

Acknowledgments: Thanks to the respondents of the surveys and $\mathrm{AB}$ Samhällsinformation for conducting the survey. Thanks also to the Swedish National Council for Nuclear Waste and especially Carl-Reinhold Bråkenhielm for support and input to the analysis. I also would like to acknowledge the great input I received from the participants at the ICAE2019 conference in Västerås, Sweden when presenting the results there. Thanks also to the three reviewers of this paper for their constructive and helpful comments.

Conflicts of Interest: The author declares no conflict of interest.

\section{References}

1. Swedish Energy Agency Energy in Sweden. Facts and Figures. 2019. Available online: https://www. energimyndigheten.se/en/news/2019/energy-in-sweden---facts-and-figures-2019-available-now/ (accessed on 19 November 2019).

2. Palm, J. Kunskapsläget Hos Sveriges Riksdagsledamöter om Kärnavfall Och Dess Slutförvar; The Swedish National Council for Nuclear Waste: Stockholm, Sweden, 2014.

3. Vedung, E. Kärnkraften Och Regeringen Fälldins Fall; Rabén \& Sjögren: Stockholm, Sweden, 1979.

4. Larsson, S.-E. Regera i Koalition: Den Borgerliga Trepartiregeringen 1976-1978 Och Kärnkraften; Bonnier: Stockholm, Sweden, 1986.

5. Lindquist, P. Det klyvbara ämnet: Diskursiva ordningar i svensk kärnkraftspolitik 1972-1980; Sociologiska Institutionen, Lund University Publications: Lund, Sweden, 1997.

6. Vedung, E.; Brandel, M. Vattenkraften, Staten Och de Politiska Partierna; Nya Doxa: Nora, Sweden, 2001.

7. Vedung, E. Det högaktiva kärnavfallets väg till den rikspolitiska dagordningen. In Kärnavfallets Politiska Utmaningar; Andrén, M., Strandberg, U., Eds.; Gidlund: Hedemora, Sweden, 2005; pp. 33-56.

8. Lidskog, R. Radioactive and Hazardous Waste Management in Sweden: Movements, Politics and Science; Uppsala Universitet: Uppsala, Sweden, 1994.

9. Lidskog, R. Kommunen Och kärnavfallet: Svensk Kärnavfallspolitik på 1990-Talet; Carlssons Bokförlag: Stockholm, Sweden, 1998.

10. Soneryd, L. Allmänhet, Expertis Och Deliberation: Samråd om Slutförvar av Kärnavfall; SCORE (Stockholms Centrum för Forskning om Offentlig Sektor): Stockholm, Sweden, 2007.

11. Johansson, H.S. Demokrati på Delegation: Lokaliseringen av Det Svenska Kärnavfallet; Avd. för Teknik-och Vetenskapsstudier, Göteborgs Universitet: Göteborg, Sweden, 2008.

12. Sundqvist, G. The Bedrock of Opinion: Science, Technology and Society in the Siting of High-Level Nuclear Waste; Kluwer Academic: Dordrecht, The Netherlands, 2002.

13. Anshelm, J. Från Energiresurs Till Kvittblivningsproblem. Frågan om Kärnavfallets Hantering $i$ Det Offentliga Samtalet i SVERIGE, 1950-2002; SKB: Stockholm, Sweden, 2006; Volume 113.

14. Wärnbäck, A. EIA Practice: Examples of Cumulative Effects and Final Disposal of Spent Nuclear Fuel; Department of Urban and Rural Development, Swedish University of Agricultural Sciences: Uppsala, Sweden, 2012.

15. Sjöberg, L. Local acceptance of a high-level nuclear waste repository. Risk Anal. 2004, 24, 737-749. [CrossRef] [PubMed]

16. Sjöberg, L. Risk perception, emotion and policy: The case of nuclear technology. Eur. Rev. 2003, 11, 109-128. [CrossRef] 
17. Sjöberg, L. Attitudes and risk perceptions of stakeholders in a nuclear waste siting issue. Risk Anal. 2003, 23, 739-749. [CrossRef]

18. Sjöberg, L.; Drottz-Sjöberg, B.M. Public risk perception of nuclear waste. Int. J. Risk Assess. Manag. 2009, 11, 264-296. [CrossRef]

19. Sjöberg, L.; Drottz-Sjöberg, B.M. Risk perception by politicians and the public. Energy Environ. 2008, 19, 455-483. [CrossRef]

20. Sjöberg, L. Opinion Och Attityder Till Förvaring av Använt Kärnbränsle; SKB: Stockholm, Sweden, 2006.

21. Kärnavfallsrådet. Kunskapsläget på Kärnavfallsområdet 2017; Kärnavfallsrådet: Stockholm, Sweden, 2017.

22. Uhrwing, M. Tillträde Till Maktens Rum: Om Intresseorganisationer Och Miljöpolitiskt Beslutsfattande; Gidlund: Hedemora, Sweden, 2001.

23. Soneryd, L. Environmental Conflicts and Deliberative Solutions?: A Case Study of Public Participation in EIA in Sweden. Doctoral Dissertation, Örebro University, Örebro, Sweden, 2002.

24. Irwin, A.; Michael, M. Science, Social Theory E Public Knowledge; McGraw-Hill Education (UK): Berkshire, UK, 2003.

25. Flynn, J.; Slovic, P.; Mertz, C. Decidedly different: Expert and public views of risks from a radioactive waste repository. Risk Anal. 1993, 13, 643-648. [CrossRef]

26. Swedish National Council for Nuclear Waste. Kunskapsläget på kärnvafallsrådet 2017; Regeringskansliet: Stockholm, Sweden, 2017.

27. Hedberg, P.; Holmberg, S. Åsikter Om Energi Och Kärnkraft. In SOM-institute. 2017. Available online: https://som.gu.se/digitalAssets/1689/1689440_32.---sikter-om-energi-och-k--rnkraft-2017.pdf (accessed on 1 October 2019).

(C) 2020 by the author. Licensee MDPI, Basel, Switzerland. This article is an open access article distributed under the terms and conditions of the Creative Commons Attribution (CC BY) license (http://creativecommons.org/licenses/by/4.0/). 